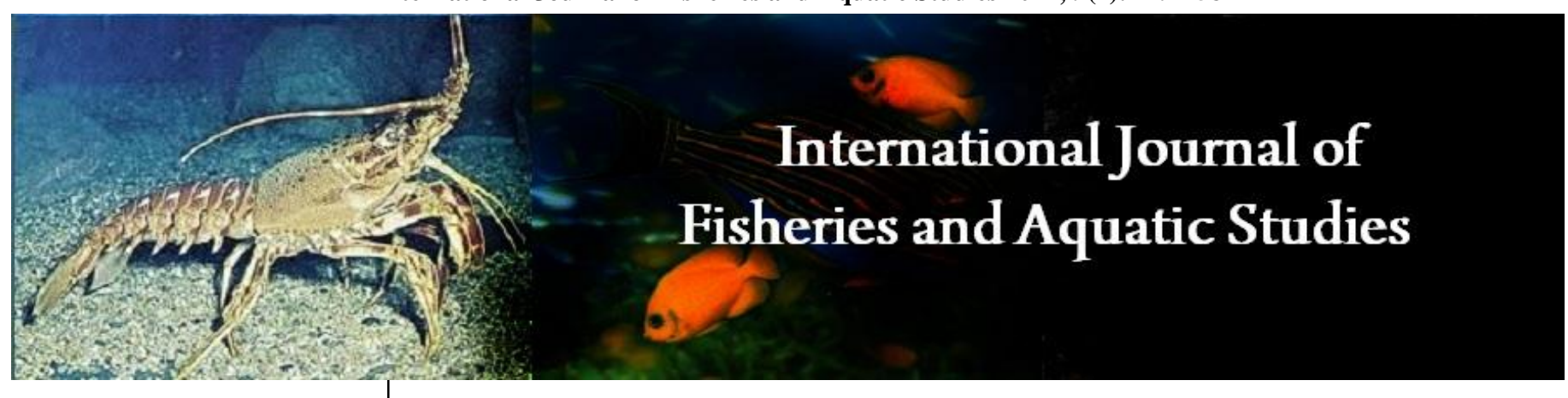

E-ISSN: 2347-5129

P-ISSN: 2394-0506

(ICV-Poland) Impact Value: 5.62

(GIF) Impact Factor: 0.549

IJFAS 2021; 9(4): 149-158

(C) 2021 IJFAS

www.fisheriesjournal.com

Received: 28-05-2021

Accepted: 30-06-2021

Augustin Kouame N'Guessan Hydrobiology and Water Eco-

Technology Laboratory,

Department of Biological

Sciences, Felix Houphouët

Boigny University, 22 Box 582

Abidjan 22, Cote d'Ivoire

Marius Tanoh Kamelan

Hydrobiology and Water Eco-

Technology Laboratory,

Department of Biological

Sciences, Felix Houphouët

Boigny University, 22 Box 582

Abidjan 22, Cote d'Ivoire

Gogbe Zeré Marius

Department of Biological

Sciences, Peleforo Gon Coulibaly

University, BP 1328 Korhogo,

Cote d'Ivoire

Valentin N'douba

Hydrobiology and Water Eco-

Technology Laboratory,

Department of Biological

Sciences, Felix Houphouët

Boigny University, 22 Box 582

Abidjan 22, Cote d'Ivoire

\section{Clandestine gold mining and pollution risks of sediments from Bagoue river (Niger watershed, Cote d'Ivoire)}

\author{
Augustin Kouame N'Guessan, Marius Tanoh Kamelan, Gogbe Zeré \\ Marius and Valentin N'douba
}

DOI: https://doi.org/10.22271/fish.2021.v9.i4b.2536

\begin{abstract}
Mercury used in gold amalgamation is a global concern and a major source of contamination and dispersion in environmental aquatic of Cote d'Ivoire, mainly in the North where clandestine gold mining activities are a local interest. The aim of this study was to assess the level of total mercury (Hg-T) contamination of sediments from Bagoue River. Water and sediments samples were collected during wet and dry seasons from six stations differently impacted. Spatial and seasonal variations in physical and chemical parameters were assessed. Results revealed that the level of $\mathrm{Hg}$ - $\mathrm{T}$ in water was $0.68 \pm 0.03 \mu \mathrm{g} . \mathrm{L}^{-}$ ${ }^{1}$ and in the sediments, dry weight concentration was $0.064 \pm 0.01 \mathrm{mg}^{-\mathrm{kg}^{-1}}$. The Hg-T concentration in sediments was significantly higher $(p<0.05)$ during the dry season $\left(0.089 \pm 0.053 \mathrm{mg} . \mathrm{kg}^{-1}\right)$ than that recorded in the wet season $\left(0.064 \pm 0.039 \mathrm{mg} . \mathrm{kg}^{-1}\right)$. Ultimately, strong and positive correlations have been observed between $\mathrm{Hg}-\mathrm{T}$ in sediments and sandy sediments $(\mathrm{r}=+1)$, as well as suspended materials $(\mathrm{r}=$ $+0.85)$. The pollution status of mercury in sediments according to the geo-accumulation index was uncontaminated (-47.03) at all the seasons whereas enrichment factor has been moderate over climatic seasons at downstream stations heavily impacted by gold mining. The sandy texture of the River sediments favours the infiltration of mercury and its accumulation in groundwater. As a rate, the health risks associated with the consumption of these waters are potentially high.
\end{abstract}

Keywords: Bagoue river, total mercury, sediment, groundwater, pollution, Cote d'Ivoire

\section{Introduction}

Aquatic ecosystems usually contain a wide variety of life forms. As a result of human actions, these environments are now modified and sometimes degraded. The alteration of one of the parameters of the environment can cause a general disturbance of the entire natural balance, especially since the resulting contamination often leads to changes in slow and sometimes brutal corn balances ${ }^{[1]}$. The degradations caused are the perpetual destruction of biotopes, the decrease in biological diversity and disturbances in the cycles of the mineral elements necessary for life ${ }^{[1]}$. Ivorian rivers are not spared from these threats, including the Bagoue River in the North of the country.

The advantages offered by main receptacle, in terms of fisheries resources, agricultural and agro-pastoral production as well as drinking water have for centuries encouraged the settlement of humans in these areas ${ }^{[2]}$. However, the impacts of anthropogenic inputs of chemical contaminants are a major concern for maintaining the good condition of aquatic systems in terms of structure and functional performance. Indeed, illicit and artisanal mining activities, which use mercury in the gold smelting ${ }^{[3]}$, have been taking place for decades in the watershed ${ }^{[2]}$. The situation worsened following the political crisis of 2002, characterized by the mis-selling of agricultural products and the ever-increasing level of poverty of local populations ${ }^{[2]}$. Some of the mercury released during gold treatment ends up in the stream ${ }^{[4]}$ and is adsorbed on particles suspended in the water. This pollutant eventually settles in sedimentation areas where it is distributed between the water column and sediments, the latter acting as the main tank ${ }^{[5 ; 6]}$. In this way, the contaminant stored in the sediments can continue to disrupt the aquatic ecosystem by affecting water and substrate quality.
Corresponding Author: Augustin Kouame N'Guessan Hydrobiology and Water EcoTechnology Laboratory, Department of Biological Sciences, Felix Houphouët Boigny University, 22 Box 582 Abidjan 22, Cote d'Ivoire 
This is why, in environmental contamination, sediments are often used as indicators for some aquatic animals living in the area also especially fishes ${ }^{[7]}$. In Cote d'Ivoire, results of aquatic chemical pollutants analysis revealed the presence of heavy metals in sediments ${ }^{[8:-12]}$. As far as the Bagoue watershed, only the work done by Mason et al. ${ }^{[12]}$ exists. The objective targeted was to assess the impact of artisanal and industrial gold mining on the level of mercury and methylmercury in environment. However, results of this study were published on the basis not only of a one-time data collection campaign conducted between August and September 2017, but was limited to downstream area, at Tengrela. Nevertheless, consideration of the inter-regional dimension of the basin, as well as the seasonal variation of pollutant are necessary to better assess the level of pollution of this River. Thus, areas where sediment exposure to mercury is most important can be identified. Measures to prevent the potential effects of this chemical pollutant on the effected ecosystem may therefore be envisaged. This study assessed the spatial and seasonal concentration of $\mathrm{Hg}-\mathrm{T}$ in sediments from Bagoue River and determined the possible enrichment factors.

\section{Material and Methods \\ 2.1. Study area}

The Bagoue River basin, tributary of the Niger stream, is situated in the North of Cote d'Ivoire between latitudes $9^{\circ} 15^{\prime}-$ $10^{\circ} 50^{\prime} \mathrm{N}$ and longitudes $5^{\circ} 40^{\prime}-7^{\circ} 10^{\prime} \mathrm{W}$ (Fig 1). The Bagoue River system has a total catchment area of about $33430 \mathrm{Km}^{2}$ [13] shared between Cote d'Ivoire, Mali and Niger. This basin has its source at west of Boundiali, in Madinani region and stretches for $350 \mathrm{~km}{ }^{[14]}$. On Ivorian territory, this watershed covers the departments of Boundiali, Kouto and Tengrela. The Bagoue watershed undergoes the influence of Soudanoguineen climate characterized by two contrasting seasons. A rainy season ranging from May to October and a dry season from November to April ${ }^{[15]}$. The water regime of Bagoue River is experiencing major irregularities. It includes a period of low flows (stretching) from November to May, and a period of high flows (crude) from June to September.

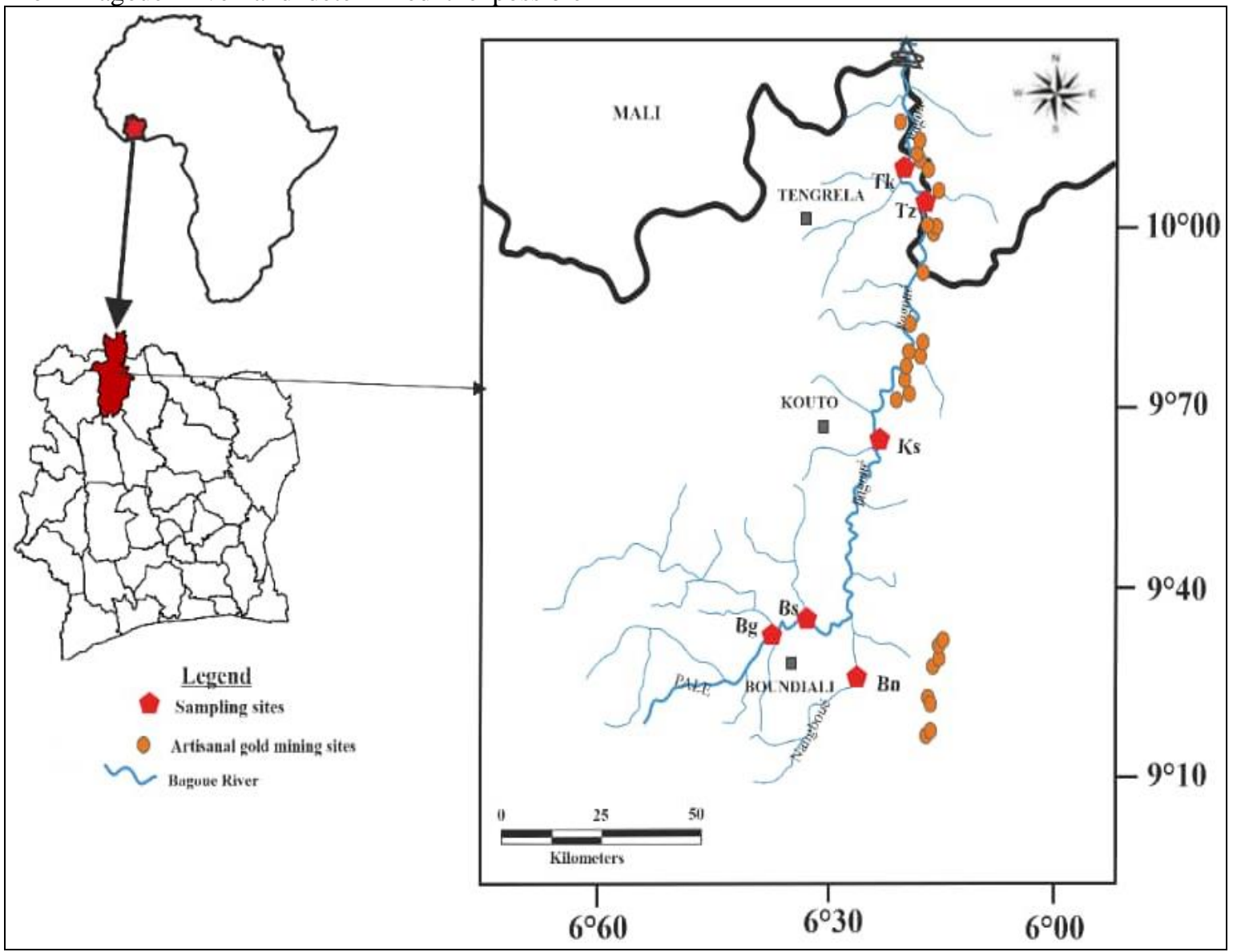

Fig 1: Map of the Bagoue River course in Cote d'Ivoire with sampling sites and some artisanal and clandestine gold mining position sites.

\subsection{Sample collection and processing}

Environmental variables were collected during the rainy (Agust-November 2018) and the dry (January-April 2019) seasons in 6 sampling sites (Fig 1). Sites whose sediment is susceptible to pollution from human activities have guided our choices. Sediments and water samples were collected from six stations between Tengrela and Boundiali. During each collection trip, two replicate samples were taken at each station. Sediment samples were excavated from an area of 25 $\mathrm{cm}$ X $25 \mathrm{~cm}^{[16]}$ with hands ${ }^{[12]}$, with depth penetration of $8 \mathrm{~cm}$ ${ }^{[17]}$. Water samples were collected using sterile gloves ${ }^{[18]}$ at a depth of $10 \mathrm{~cm}{ }^{[17]}$. They were then stabilized by addition of 1 $\%$ concentration hydrochloric acid ${ }^{[19]}$. All samples were kept in relabelled polyethylene vials, wrapped in aluminium foil and stored at 4 degrees to the laboratory according to CEAEQ ${ }^{[20]}$ and AFNOR ${ }^{[19]}$. The water parameters (temperature, $\mathrm{pH}$, electrical conductivity, total dissolved solids) were measured in surface, with a portable multi-parameter probe, HANNA HI 9828. Water transparency was measured using a Secchi disk. Total solids suspended were balanced using vacuum filtration method with a fiberglass filter of nominal porosity estimated at $1.5 \mu \mathrm{m}$ according to AFNOR ${ }^{[21]}$. $\mathrm{Hg}-\mathrm{T}$ and iron were 
analyzed by atomic absorption spectrophotometry equipped with a cold vapour system (VGA 77). All analyses were done in three remnants per parameter. For sediment-texture analysis, samples were dried at $100{ }^{\circ} \mathrm{C}$ for $72 \mathrm{~h}$, and sieved using a column of sieve according to AFNOR ${ }^{[19]}$. Grain size was analyzed following a method described by Ibouilly ${ }^{[2]}$.

\subsection{Assessment of sediments contamination}

The geochemical accumulation index (Igeo) was employed as a quantitative tool to assess the level of $\mathrm{Hg}$ - $\mathrm{T}$ contamination in sediments. This index was calculated using Equation (1) proposed by Müller ${ }^{[23]}$.

Igeo $=\frac{\log _{2}(\mathrm{Cs})}{1.5 \times \mathrm{Bg}}$

Where $C s$ is the sediment metal concentration; 1.5 is the constant for modifying the fluctuation of the background value caused by lithological movement ${ }^{[24]}$ and $\mathrm{Bg}$ is the geochemical background value of the metal. In this work, $0.056 \mathrm{mg} \cdot \mathrm{kg}^{-1}$ was the reported background value utilized ${ }^{[25]}$. Based on the results, mercury pollution of sediment was classified into seven categories according to Müller ${ }^{[23]}$.

\subsection{Enrichment Factor (EF) determination}

$\mathrm{EF}$ is a useful indicator that reflects the condition of environmental contamination. In this study, mercury concentrations are normalized as ratios to another constituent of the sediment, to evaluate the possible anthropogenic input of $\mathrm{Hg}$-T. In order to compensate for grain size effect which has considerable bearing on the concentration of contaminants in sediment/soil, a normalization with conservative element measured in the same sample is often adopted. In this study, Iron was chosen because of the lateritic character and deposited iron oxide abundance in northern soils of the country. Mercury and iron levels in the Earth's continental crust were $0,056 \mathrm{mg} \cdot \mathrm{kg}^{-1}$ and $30890 \mathrm{mg} \cdot \mathrm{kg}^{-1}$ respectively according to Wedepohl ${ }^{[26]}$. The EF is calculated using Equation (2) proposed by Jayaprakash ${ }^{\text {[27]: }}$

$$
\mathrm{FE}=\frac{\mathrm{Hg}_{\mathrm{s}} / \mathrm{Fe}_{\mathrm{s}}}{\mathrm{Hg}_{\mathrm{ref}} / \mathrm{Fe}_{\mathrm{ref}}}
$$

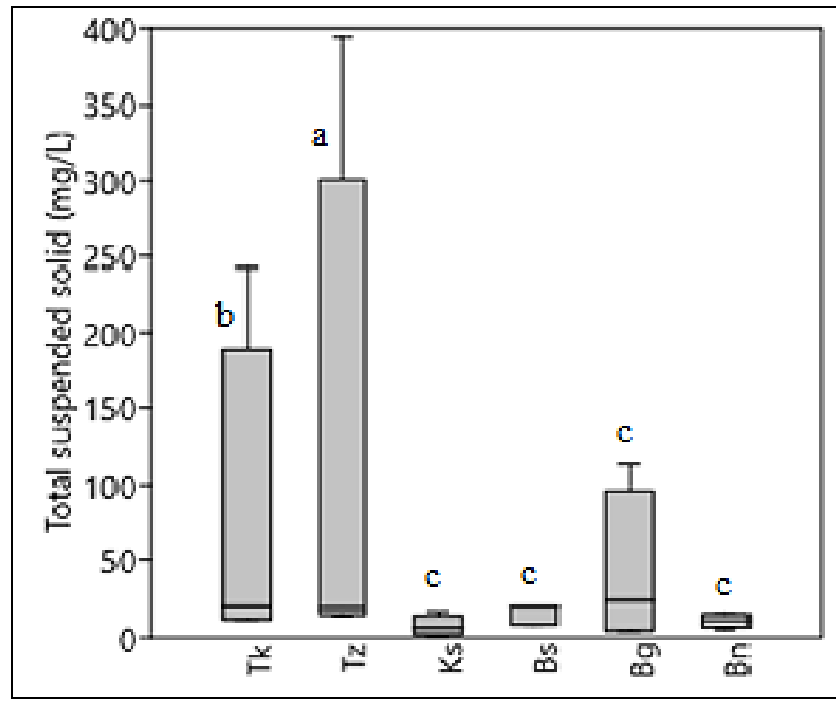

A.
Where $\mathrm{Hg}_{\mathrm{s}} / \mathrm{Fe}_{\mathrm{s}}$ is the ratio of mercury $(\mathrm{Hg})$ to Iron $(\mathrm{Fe})$ concentration determined in the sediment and $\mathrm{Hg}_{\text {ref }} / \mathrm{Fe}_{\text {ref }}$ is the ratio based on background values. Hakanson ${ }^{[29]}$ suggest the following intervals to determine the sources of sediment contamination based on the enrichment factor: $\mathrm{EF}<1$ refers to no enrichment; $\mathrm{EF}$ from 1 to 3 to minor enrichment; $\mathrm{EF}$ from 3 to 5 to moderate enrichment; $\mathrm{EF}$ from 5 to 10 to moderately-highly enriched; EF from 10 to 25 to significant enrichment; EF from 25 to 50 to very high enrichment; and $\mathrm{EF}>50$ to extremely high enrichment.

\subsection{Statistical analysis}

Before performing comparison test, normality of data was verified by Shapiro-Wilk test at critical value of 0.05 . Data for sediment particle size, mercury levels and other environmental parameters were statistically compared among stations using a Kruskall-Wallis test ${ }^{[28]}$. Significance was tested at an alpha value of 5\%. Mann-Whitney test was used to verify the significance of seasonal variation data. Correlations between environmental parameters, such as gravel, sand, clay, suspended matter and mercury levels were statistically tested using simple correlation matrix of Spearman. All statistical analyses were performed by using XLSTAT 2016.

\section{Results}

\subsection{Water characteristics}

The results of spatial analysis of water parameters are presented by Fig 2. Kruskall-Wallis data test reveals a significant difference $(P<0.05)$ between sites for suspended materials and transparency. Highest total suspended solids $\left(111.58 \pm 188.29 \mathrm{mg} . \mathrm{L}^{-1}\right)$ were observed at Zanikaha $(\mathrm{Tz})$ and Kanakono $\left(\mathrm{T}_{\mathrm{K}}\right)$ sites, downstream, whereas lowest $(7.61 \pm 6.78$ $\mathrm{mg} . \mathrm{L}^{-1}$ ) were obtained at Kouto site (Ks), still downstream. It was also showed that transparency values were generally lower in the sampling sites located downstream (22.25 \pm 13.5 $\mathrm{cm}$ at $\mathrm{Tz}$ site and $28.5 \pm 19.46 \mathrm{~cm}$ at Tk site), as well as in the tributary $(19.87 \pm 9.04 \mathrm{~cm})$. The highest value of transparency $(55.75 \pm 8.73 \mathrm{~cm})$ was observed upstream at Samorosso site (Bs).

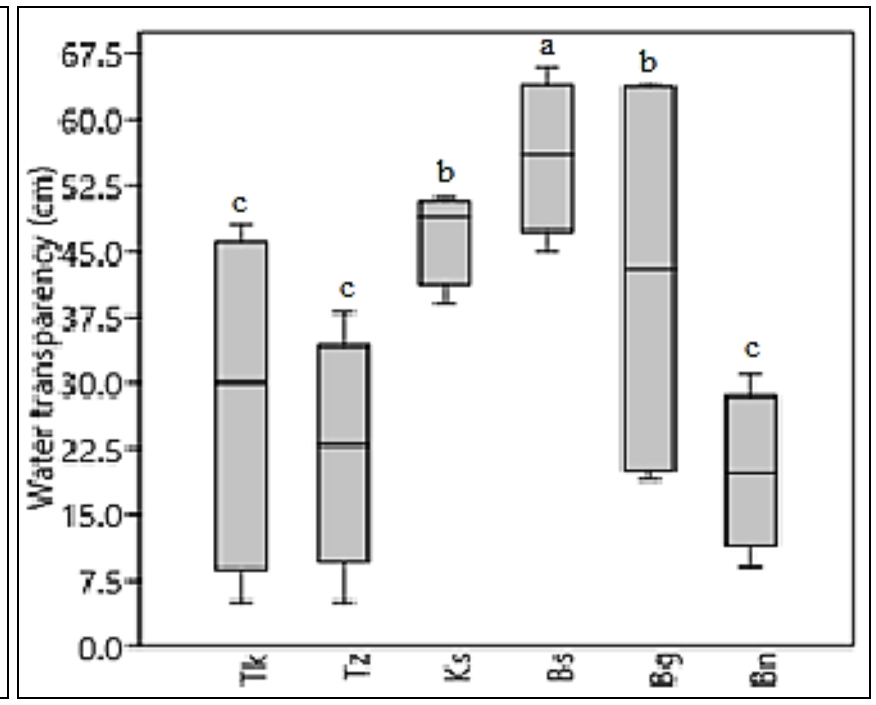




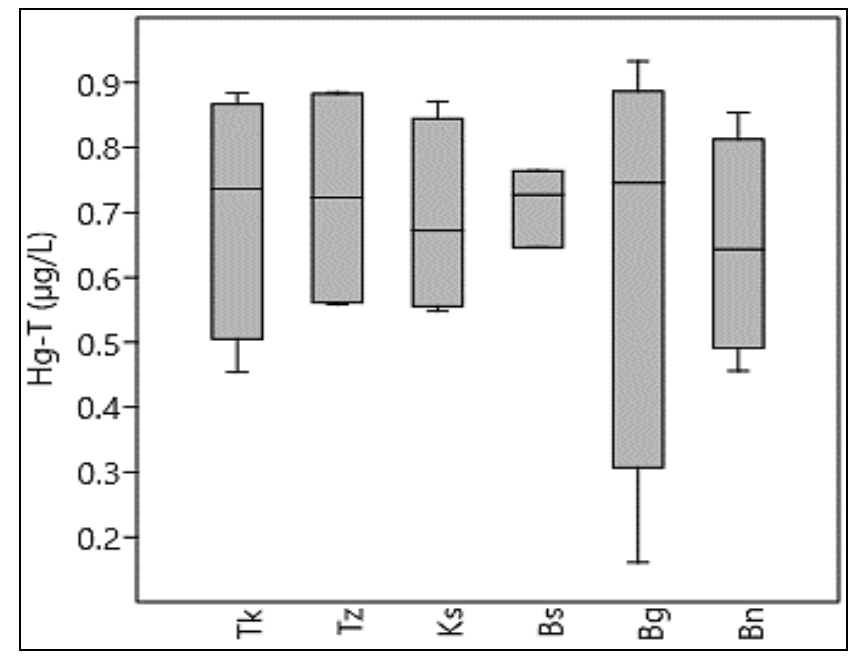

C.

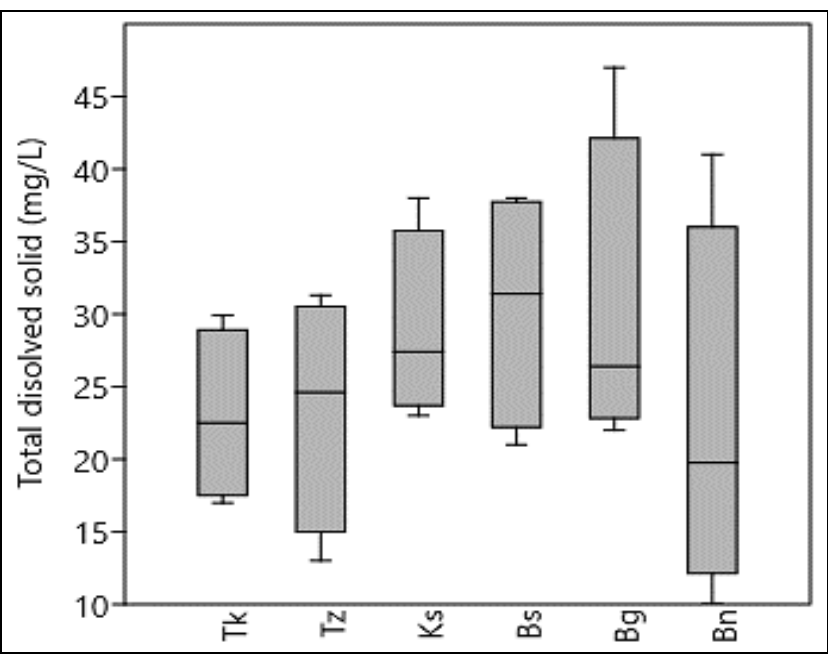

E.

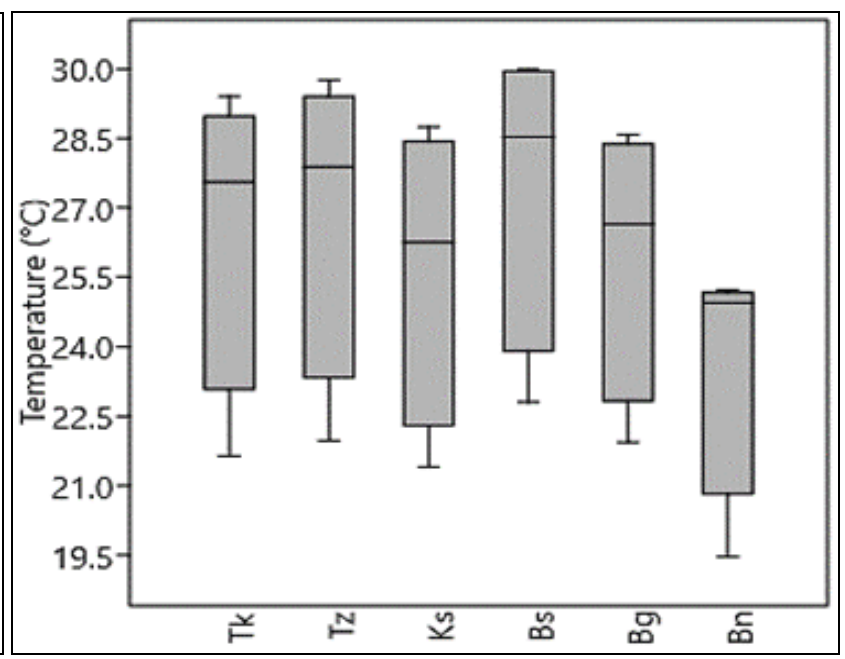

D.

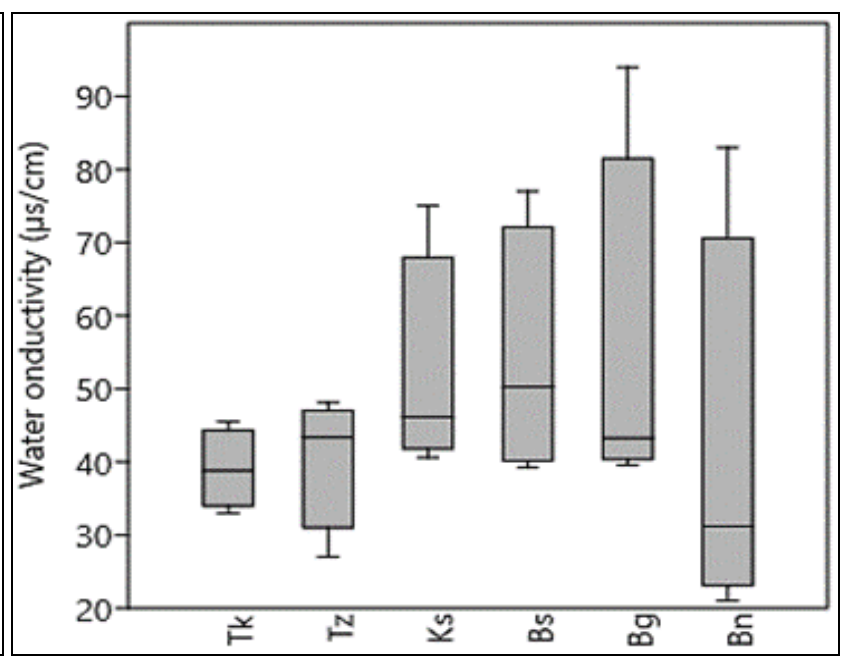

F.

Fig 2: Spatial concentration of water parameters of Bagoue River measured from August 2018 to April 2019. (A) Total suspended solids, (B) Transparency, (C) Total mercury, (D) Temperature, (E) Total dissolved solids, (F) Conductivity. a, b, c indicate a significant difference (p < $0.05)$.

Seasonally, total suspended solids showed significant variations (Mann-Whitney, $p<0.05$ ) (Fig. 3). Concentration of total suspended solids (TSS) in water was higher in the dry season with an overall mean concentration of $75.74 \pm 80.02$ mg. $\mathrm{L}^{-1}$ compared to $10.89 \pm 7.06 \mathrm{mg} . \mathrm{L}^{-1}$ for the wet season.

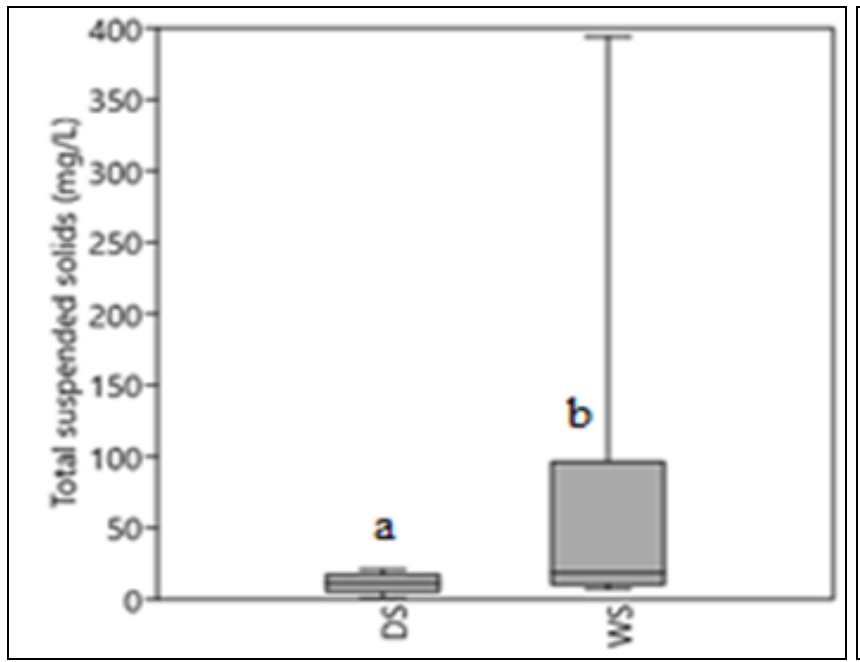

A.

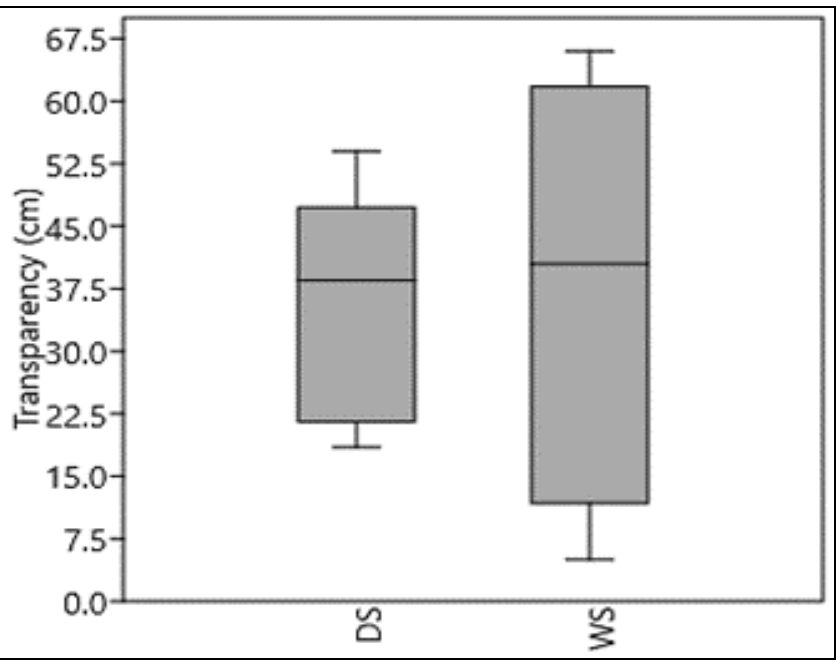

B. 


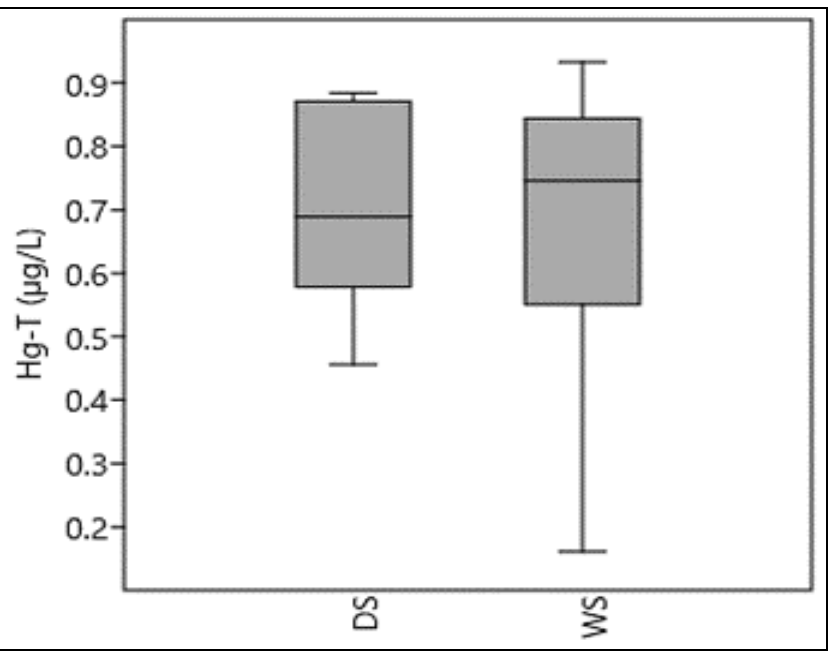

C.

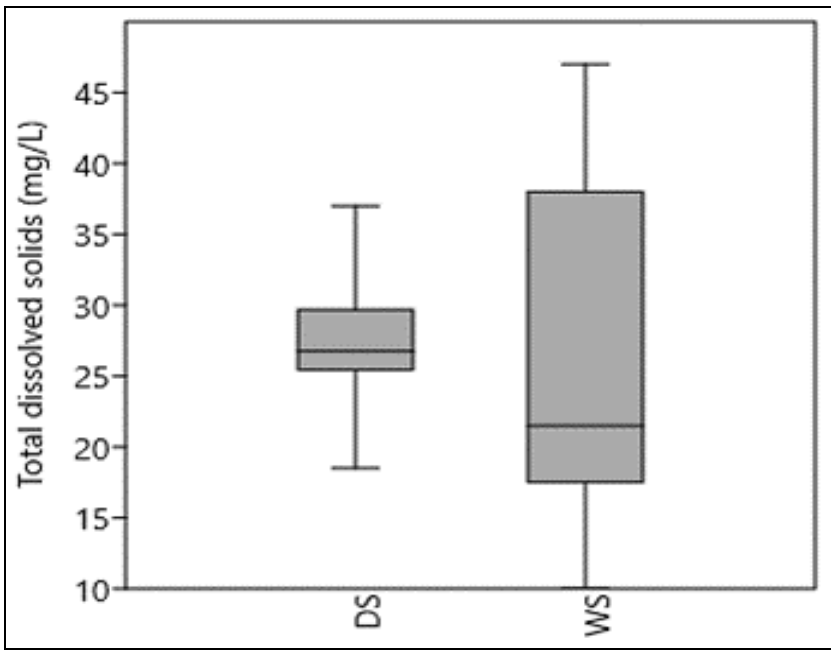

E.

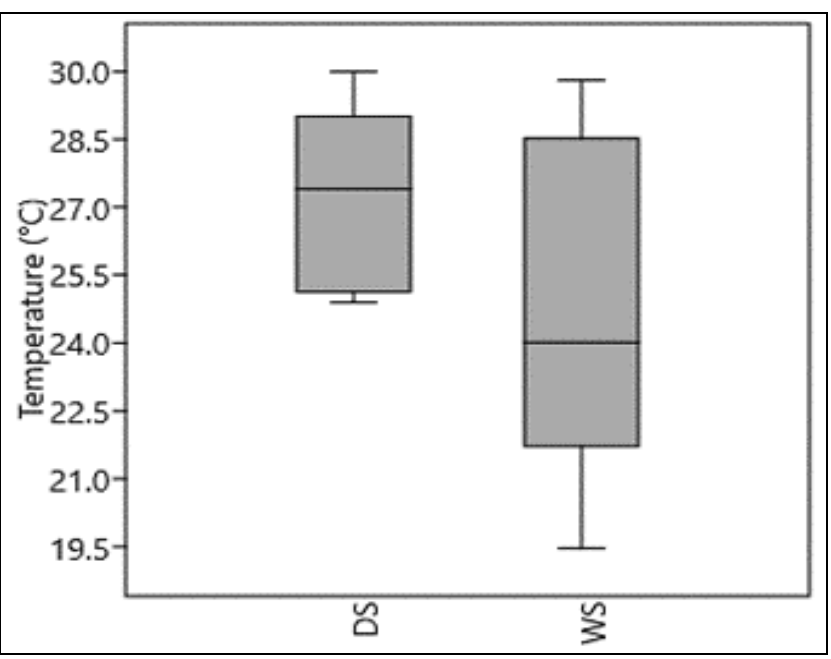

D.

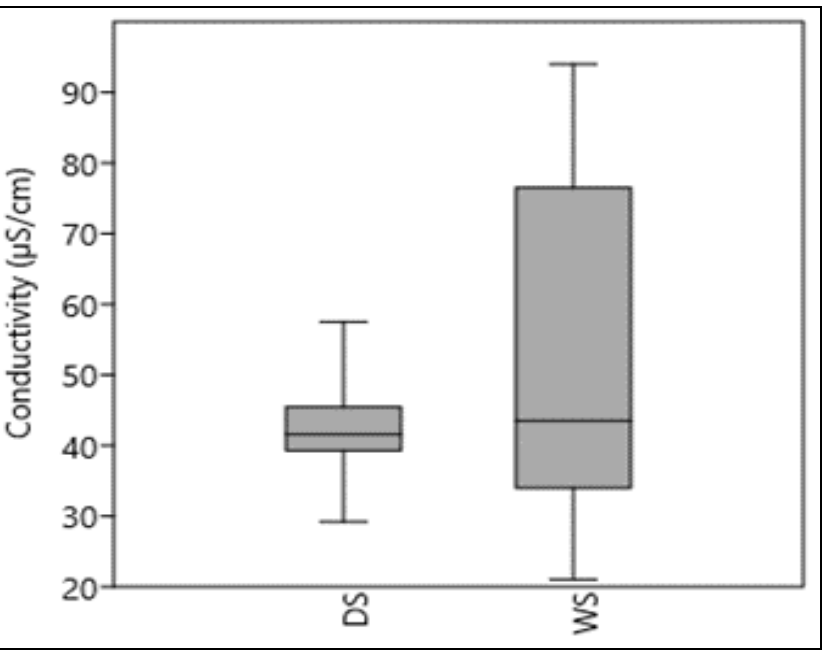

F.

Fig 3: Seasonal concentration of water parameters of Bagoue River from August 2018 to April 2019. WS= wet season; DS = dry season. (A) Total suspended solids, (B) Transparency, (C) Total mercury, (D) Temperature, (E) Total dissolved solids, (F) Conductivity. a, b indicate a significant difference $(\mathrm{p}<0.05)$.

\subsection{Sediments characteristics}

The study also looked at sedimentary parameters. Data collected for spatial and seasonal analysis of sediments are presented in Table 1. Taking into account annual averages on each site, no spatial variation was observed (Kruskall-Wallis, $p>0.05)$ for all the parameters measured. Seasonally however, there were significant differences (Mann-Whitney, $p$ $<0.05)$ for the $\mathrm{T}-\mathrm{Hg}$ and grain size data of sediments. The average concentration of $\mathrm{T}-\mathrm{Hg}$ in sediments was higher (0.089 mg.kg-1) during dry season than the rate recorded $\left(0.036 \mathrm{mg} . \mathrm{kg}^{-1}\right)$ during wet season. The proportions of clay and sand were higher (respectively $2.54 \%$ and $89.02 \%$ ) during rainy season than the percentages (respectively $0.82 \%$ and $75.99 \%$ ) obtained on the dry season. The percentage of gravel on the other hand was higher in sediments $(22.94 \%)$ during dry season than rainy season $(6.9 \%)$.

Table 1: Results of seasonal variation of sediments characteristics from Bagoue River

\begin{tabular}{|c|c|c|c|c|c|c|c|c|c|c|c|c|}
\hline \multirow{3}{*}{ Sites } & \multicolumn{6}{|c|}{ Chemical parameters } & \multicolumn{6}{|c|}{ Sediments texture (\%) } \\
\hline & \multicolumn{2}{|c|}{ Iron (mg.kg-1) } & \multicolumn{2}{|c|}{ Water of Sediments (\%) } & \multicolumn{2}{|c|}{ T-Hg (mg.kg-1) } & \multicolumn{2}{|c|}{ Clay $(\mathrm{D} \leq 63 \mu \mathrm{m})$} & \multicolumn{2}{|c|}{ Sand $(2 \mathrm{~mm}>\mathrm{D}>63 \mu \mathrm{m})$} & \multicolumn{2}{|c|}{ Gravel $(\mathrm{D} \geq 2 \mathrm{~mm})$} \\
\hline & WS & DS & WS & DS & WS & DS & WS & DS & WS & DS & WS & DS \\
\hline Tk & 5668.93 & 14212.3 & 23.65 & 42.2 & 0.046 & 0.132 & 4.1 & 0.7 & 86.9 & 84.85 & 5.76 & 14.33 \\
\hline $\mathrm{Tz}$ & 10040.2 & 12369.4 & 30.2 & 27.87 & 0.033 & 0.122 & 1.74 & 0.97 & 79.95 & 90.51 & 17.84 & 8.5 \\
\hline Ks & 8725.09 & 7487.28 & 20.75 & 42.75 & 0.056 & 0.06 & 2.53 & 0.46 & 95.17 & 68.3 & 1.33 & 31.2 \\
\hline Bs & 18373.2 & 26190.8 & 42 & 47.6 & 0.012 & 0.061 & 1.58 & 0.86 & 91.21 & 66.69 & 6.59 & 32.11 \\
\hline $\mathrm{Bg}$ & 12369.4 & 29826 & 39.97 & 36.62 & 0.035 & 0.087 & 2.42 & 0.74 & 92.57 & 72.41 & 3.18 & 26.31 \\
\hline $\mathrm{Bn}$ & 12369.4 & 21329.1 & 42.77 & 51.25 & 0.034 & 0.069 & 2.86 & 1.22 & 88.35 & 73.2 & 6.73 & 25.22 \\
\hline Min & 5669 & 7487 & 20.75 & 27.87 & 0.012 & 0.012 & 1.45 & 0.22 & 66.09 & 51.34 & 0 & 0.82 \\
\hline \begin{tabular}{|l|} 
Max \\
\end{tabular} & 18373 & 29826 & 42.77 & 51.25 & 0.064 & 0.168 & 6.1 & 1.75 & 96.5 & 98.15 & 31.74 & 48.05 \\
\hline Aver. & 11258 & 18569 & 33.22 & 41.38 & 0.036 & 0.089 & 2.54 & 0.82 & 89.02 & 75.99 & 6.9 & 22.94 \\
\hline St-er. & 4295 & 8633 & 9.69 & 8.29 & 0.015 & 0.053 & 1.27 & 0.43 & 8.42 & 13.91 & 8.44 & 14.11 \\
\hline
\end{tabular}

Min = minimum, Max = maximum, St-er $=$ standard error, $\mathrm{D}=$ particle diameter, $\mathrm{WS}=$ wet season, $\mathrm{DS}=$ dry season 


\subsection{Levels and sources of sediments contamination}

In order to assess the level of sediment pollution and to determine the potential sources of mercury contamination, the Muller's geochemical index (Igeo) and enrichment factors (EF) were determined. The recorded values are shown in the Table 2. No significant difference in the Igeo data for the sampling sites (Krukall-Wallis, $p>0.05$ ) and the climate seasons (Mann-Whitney, $p>0.05$ ) were reported. Igeo values ranged from -32.45 ( $\mathrm{Tk}$ site) to - 45.09 (Ks site) for rainy season and from -46.2 (Ks site) to -70.89 (Bs site) for wet season. The values of Igeo for $\mathrm{Hg}-\mathrm{T}$ evaluated in the wet and dry season for all samples exhibited a zero class.

Also, no significant variations of EF (Mann-Whitney, $p>$
0.05) were reported between the climatic seasons. On the other hand, the sediment EF of samples from downstream sites influenced by artisanal gold mining were significantly different (Krukall-Wallis, $p<0.05$ ) from those of upstream sites. EF values ranged from 1.73 to 3.28 in rainy season and from 3.79 to 4.89 in wet season for samples from downstream. On the Hakanson ${ }^{[29]}$ scale, EF values calculated using average $\mathrm{Hg}$ - $\mathrm{T}$ concentrations in the wet and dry seasons showed moderate anthropogenic enrichment $(3<\mathrm{EF}<5)$ at downstream sediments. On the contrary, anthropogenic enrichment of upstream sediments has been minor $(1<\mathrm{EF}<$ 3) over all climatic seasons.

Table 2: Geo index values and surface sediment enrichment factors of the Bagoue River measured from Agust 2018 to April 2019.

\begin{tabular}{|c|c|c|c|c|}
\hline Sites & \multicolumn{3}{|c|}{ Sedimentary index } \\
\hline & DS & WS & DS & WS \\
\hline & -32.45 & -49.35 & 3.28 & 4.89 \\
\hline $\mathrm{Tk}$ & -33.72 & -52 & 3.01 & 4.47 \\
\hline $\mathrm{Tz}$ & -45.09 & -46.2 & 1.73 & 3.79 \\
\hline $\mathrm{Ks}$ & -44.83 & -70.89 & 1.28 & 1.83 \\
\hline $\mathrm{Bs}$ & -39.14 & -53.73 & 2.25 & 2.8 \\
\hline $\mathrm{Bg}$ & -42.85 & -54.2 & 1.28 & 2.08 \\
\hline $\mathrm{Bn}$ & &
\end{tabular}

Igeo = geochemical index; EF = enrichment factor; ws = wet season; DS = dry season

\subsection{Correlation analysis}

Spearman correlation test applied to the data (Table 3) showed several significantly correlation. $\mathrm{Hg}$-T levels increase in sediments as the amount of sand increases. This translates into a very high correlation coefficient $(\mathrm{r}=1.00)$. Similarly, $\mathrm{Hg}-\mathrm{T}$ and suspended materials are strongly linked positively $(\mathrm{r}=0.85)$. On the other hand, Hg-T levels in sediments become low when the amount of gravel is high in sediments. Hence the high negative correlation coefficient $(r=-0.94)$ observed. In addition, an inversely proportional change in $\mathrm{Hg}$ $\mathrm{T}$ levels in sediments and water $\mathrm{pH}$ has been observed with a very significant coefficient $(\mathrm{r}=-0.84)$. Likewise, gravel was negatively correlated $(r=-0.94)$ to sandy particles. Finally, data showed that the rate of dissolved substances increases as water transparency increases. Similarly, the increase in the rate of dissolved substances also leads to an increase in the water conductivity. These correlations translate into coefficients (r) of 0.84 and 0.81 respectively.

Table 3: Correlations matrix between physical and chemical parameters measured in Bagoue River's water and sediments from August 2018 to April 2019.

\begin{tabular}{|c|c|c|c|c|c|c|c|c|c|c|c|c|c|}
\hline Variables & $\mathbf{H g}_{\mathbf{s}}$ & $\mathbf{F e}_{\mathbf{s}}$ & $\mathbf{T w}_{\mathbf{s}}$ & $\mathbf{C l a y}_{\mathbf{s}}$ & $\mathbf{S a n d}_{\mathbf{s}}$ & $\mathbf{G r a v}_{\mathbf{s}}$ & $\mathbf{H g}_{\mathbf{w}}$ & $\mathbf{C o n}_{\mathbf{w}}$ & $\mathbf{T}^{\circ} \mathbf{C}_{\mathbf{w}}$ & $\mathbf{p H}_{\mathbf{w}}$ & $\mathbf{T D S}_{\mathbf{w}}$ & $\mathbf{T r a n}_{\mathbf{w}}$ & $\mathbf{T S S}_{\mathbf{w}}$ \\
\hline $\mathrm{Hg}_{\mathrm{s}}$ & 1 & & & & & & & & & & & & \\
\hline $\mathrm{Fe}_{\mathrm{s}}$ & -0.54 & 1 & & & & & & & & & & & \\
\hline $\mathrm{Tw}_{\mathrm{s}}$ & -0.65 & 0.65 & 1 & & & & & & & & & & \\
\hline $\mathrm{Arg}_{\mathrm{s}}$ & 0.48 & -0.37 & 0.20 & 1 & & & & & & & & & \\
\hline $\mathrm{Sand}_{\mathrm{s}}$ & 1.00 & -0.54 & -0.65 & 0.48 & 1 & & & & & & & & \\
\hline $\mathrm{Grav}_{\mathrm{s}}$ & -0.94 & 0.37 & 0.42 & -0.60 & -0.94 & 1 & & & & & & & \\
\hline $\mathrm{Hg}_{\mathrm{w}}$ & 0.20 & -0.05 & -0.55 & -0.58 & 0.20 & -0.11 & 1 & & & & & & \\
\hline $\mathrm{Con}_{\mathrm{w}}$ & -0.60 & 0.60 & 0.37 & -0.42 & -0.60 & 0.65 & -0.40 & 1 & & & & & \\
\hline $\mathrm{T}^{\circ} \mathrm{C}_{\mathrm{w}}$ & 0.08 & 0.37 & -0.25 & -0.60 & 0.08 & -0.02 & 0.80 & -0.02 & 1 & & & & \\
\hline $\mathrm{pH}_{\mathrm{w}}$ & -0.84 & 0.25 & -0.37 & -0.64 & -0.25 & 0.42 & 0.72 & 0.31 & 0.77 & 1 & & & \\
\hline $\mathrm{TDS}_{\mathrm{w}}$ & -0.29 & 0.46 & -0.05 & -0.63 & -0.29 & 0.46 & 0.10 & 0.81 & 0.46 & 0.69 & 1 & & \\
\hline $\mathrm{Tran}_{\mathrm{w}}$ & -0.37 & 0.20 & -0.02 & -0.54 & -0.37 & 0.60 & 0.17 & 0.60 & 0.42 & 0.65 & 0.84 & 1 & \\
\hline $\mathrm{TSS}_{\mathrm{w}}$ & 0.85 & 0.08 & -0.42 & 0.02 & 0.71 & -0.77 & 0.55 & -0.42 & 0.60 & 0.14 & -0.05 & -0.31 & 1 \\
\hline \multicolumn{8}{|c|}{ Significance was tested at an alpha value of 0.05 for bold values } & & & & & \\
\hline
\end{tabular}

$\mathrm{s}=$ sediment, ${ }_{\mathrm{w}}=$ water, $\mathrm{Tw}_{\mathrm{s}}=$ water sediment content, $\mathrm{Grav}_{\mathrm{s}}=$ gravel, $\mathrm{Con}_{\mathrm{w}}=$ water conductivity, $\mathrm{TDS}_{\mathrm{w}}=\mathrm{water}_{\text {total dissolved }}$ solids, TSS $=$ total suspended solids

\section{Discussion}

Toxic metals released into environment as a result of natural processes or human activities enter River system and eventually accumulate in sediment. The analysis of sediment samples is particularly recommended for identifying the sources of metals and for reconstructing the impact of (past) human activities on the spatial and seasonal variations of metal fluxes ${ }^{[30]}$. Water and sediment study from Bagoue
River revealed the presence of $\mathrm{Hg}-\mathrm{T}$. The average concentration observed in sediment was not significantly different from average $\left(0.056 \mathrm{mg} . \mathrm{kg}^{-1}\right)$ content in earth's crust [25]. Values obtained were below the tolerable maximum limit for freshwater sediment quality criteria $\left(0.81 \quad \mathrm{mg} \cdot \mathrm{kg}^{-1}\right)$ suggested by the International Atomic Energy Agency [31]. The similar study conducted by Mason et al. ${ }^{[12]}$ in area at Tengrela and the artisanal gold mining at Bonikro village 
(Centre of Cote d'Ivoire) showed lower mercury levels (0.012 mg. $\left.\mathrm{kg}^{-1} ; 0.015 \mathrm{mg} . \mathrm{kg}^{-1}\right)$ than data collected during present study.

The absence of significant spatial variation in sediment parameters suggests the existence of substantially similar characteristics of the Bagoue River substrate. However, at the Hg-T level, the spatial characteristics of its distribution indicate a relative increase in its sediment content, mainly in downstream artisanal mining areas, although no significant differences were observed between downstream and upstream referential sites. But, while mining activity appears to be the cause, it should be noted that sediment metal concentrations do not systematically induce anthropogenic influence ${ }^{[32 ; 33]}$. Seasonal climatic variations have significantly impacted the process of metal concentration in sedimentary particles. During dry season, there is increased mining activity with decreasing mercury mobility in the River systems due to reduced water levels and flow rate. As a result, mercurycontaminated particles frequently settle at the bottom of the River. Comparatively, in the wet season, much lower mercury values were observed in samples collected due to high flow regimes characteristics of this season resulting in the dilution and dispersal of mercury particles. Furthermore, mining activities tend to slow down during the rainy season due to the inability to access flooded galleries and River alluvials. Therefore, the release of mercury residues into the environment during the processing of gold ore is reduced. Findings from this study are similar to studies conducted in the Gambia River (Senegal) and in the Asutifi District (Ghana), respectively by Niane et al. ${ }^{[34]}$ and Kyereme et al. ${ }^{[35]}$. In contrast, Gerardo et al. ${ }^{[36]}$ showed highest average values in the wet season $\left(0.24 \mathrm{mg} \cdot \mathrm{kg}^{-1}\right)$ than in the dry season $\left(0.19 \mathrm{mg} \cdot \mathrm{kg}^{-1}\right)$.

Owing that determination of metal trace concentration is insufficient to provide their sources and degree of accumulation in the environment, the enrichment factor (EF) and geo accumulation indexes (Igeo) were performed to estimate contamination degree of sediment samples ${ }^{[37]}$. The range of EF values obtained during the dry and the wet season, with a moderate enrichment at downstream, indicate an anthropogenic source of mercury probably from activities such as industrialisation, urbanisation, deposition of industrial and household wastes, agriculture and others. However, since the study area is remote from all industrial activities, it is inferred that mercury in sediment is mainly the consequence of artisanal gold mining activities. Indeed, several steps in the processing of gold-containing, such as crushing and amalgamation release trace metals into the environment. This study therefore suggests a link between artisanal gold mine that abound downstream at Tengrela region, and mercury contamination of stream sediment. The environmental contamination with traces elements by artisanal mining activities found in the present study is in agreement with previous investigations in Cote d'Ivoire [11], in Ghana [38; 35] and in Senegal ${ }^{[34 ; 39]}$. Likewise, Niane et al. ${ }^{[40]}$ found elevated concentrations of $\mathrm{Hg}-\mathrm{T}$ (39 times higher) around artisanal and small gold mining at downstream site in Bantako than upstream reference site at Samekouta in the Gambia River. Rather, minor upstream sediment enrichment is associated with a cumulative effect due to the drainage of contamination sediment from adjacent gold mining sites

According to Müller [23], the values of Igeo for $\mathrm{Hg}$ - $\mathrm{T}$ evaluated in the wet and dry seasons for all samples exhibited a zero class, indicating unpolluted sediment quality. How to explain this result when it has been show that these sediments are subject to anthropogenic enrichment regardless of climatic seasons. Data related to the study of sediment texture could guide our discussion. Indeed, the study revealed a clay-silt proportion of less than $10 \%$ characteristic of the pure sandy texture of the sediments. In agreement with Lochu et al. ${ }^{[41]}$, such a percentage of fine particles (diameter $\leq 63 \mu \mathrm{m}$ ) in granulometry reduces the ability of mercury to be adsorbed by surface sediment. As a result, most of the mercury introduced into the River system is leached and migrates to the groundwater. The other part is transported to the terminal basins much further downstream. Similar comments were made by Donkor et al. ${ }^{[38]}$ in the Pra River, Ghana.

The determination of correlation coefficient provides an idea of the possible relationship between metals and parameters of the study environment: homogeneous distribution, identical behaviour in the physical and chemical processes and influence of one on the other. Results show a strong influence of sandy fraction on the level of $\mathrm{Hg}-\mathrm{T}$ in sediment. Given the low affinity between sand and mercury ${ }^{[41]}$, this statistical link may suggest that some of the mercury is present in elementary or particulate form in interstitial water and/or attached to the gold residues present in the sediment as described by Guedron [42] in a gold mining basin in French Guiana. However, mercury can be found in the sandy fraction in case of a coasting of the grains by mercury sulphide $(\mathrm{HgS})$ or clay ${ }^{[43]}$. A similar correlation has been reported by Niane et al. ${ }^{[34]}$. Moreover, the strong correlation between $\mathrm{Hg}-\mathrm{T}$ and suspended material suggests a particulate behaviour of the metal in this aquatic environment. Indeed, sediment enrichment depends on a deposit of suspended solid particles whose affinity for metal trace elements has been demonstrated by many studies $[43 ; 44 ; 45 ; 46]$. Furthermore, the study shows negative correlation between $\mathrm{Hg}$ - $\mathrm{T}$ and coarse particles due to their very narrow adsorption surface for metal trace elements, in agreement with findings of several studies ${ }^{[47 ; 48 ; 41]}$. Finally, the significant negative correlation between $\mathrm{Hg}-\mathrm{T}$ and $\mathrm{pH}$ could suggest a control of this water parameter on the pollutant distribution. Indeed, he was admitted that acidic water promote the emergence of the dissolved form of heavy metal in interstitial sediment water, hence the reduction of percentage of fixation on sedimentary particles. This negative influence of $\mathrm{pH}$ on mercury's adherence to sediment has already been mentioned by Thomassin et al. ${ }^{[43]}$; Guigues and Corroller ${ }^{[43 ; 44]}$

Clandestine and small-scale gold mining activities are likely to cause significant sediment pollution by heavy metals. As a result, their presence in the substrate of streams, negatively impacts the life of benthic organisms. They can also have a negative impact on the local environment and freshwater resources [49]. The main environmental risk is the remobilization of these contaminants and their return to the hydrosphere either by re-suspending sediments or by infiltration into groundwater ${ }^{[50]}$. In the Bagoue basin, mercury seeping into the subsoil is likely contaminating groundwater and poses a health risk to local populations. Indeed, a study conducted in a gold mining environment in the Department of Oume (center of Cote d'Ivoire) by Niamké et al. ${ }^{[51]}$, revealed an average mercury content of $0,87 \mu \mathrm{g} . \mathrm{L}^{-1}$ in groundwater. Similarly, the study undertaken by Konan et al. ${ }^{\text {[52] }}$ revealed the health risks faced by populations with hazard quotients estimated to be greater than 1 for arsenic and mercury in the groundwater in Ity's gold mining environment (North of Cote d'Ivoire). Likewise, Yapi et al. ${ }^{[53]}$ found 
levels of mercury, arsenic, nickel, cadmium and lead well above WHO's limits for drinking water in a mining gold environment in Hire (South of Cote d'Ivoire).

\section{Conclusion}

The aim of this study was to investigate the impact of clandestine and artisanal gold mining. Our research has been directed towards the surface sediment of Bagoue River, in areas downstream and upstream of the watershed. The results obtained make it possible to highlight the interest of the fight against illegal gold mining. The results suggested that clandestine mining activities significantly contribute to the considerable sedimentary mercury contamination in both downstream River basin. In addition, the hypothesis of a mercury accumulation in groundwater is highly plausible given the sandy texture of the River sediment. Therefore, mercury levels should carefully monitored and con-trolled to reduce its inputs and mitigate potential health consequences of its accumulation in the environment. We recommend an assessment study of the level of groundwater contamination by heavy metals to prevent any health risks for local populations.

\section{Acknowledgements}

Part of sample pre-treatment was performed at LANADA research Laboratory (Abidjan, Cote d'Ivoire) and at Ecology Research Centre. Author thankful to Kouyate Kassoum, Bouah Fabrice, Adouko Desire and Amani Reine for their help during collecting samples.

\section{References}

1. Concas A, Ardau C, Cristini A, Zuddas P, Cao G. "Mobility of heavy metal from tailing to stream waters in a mining activity contaminated site". Chemosphere. 2006;63:244-253. https://doi.org/10.1016/j.chemosphere.2005.08.024.

2. Koné B. "Fièvre de l'or et le devenir des activités rurales dans le département de Tengréla (nord de la Côte d'Ivoire)". Institut de Géographie Tropicale (IGT), Université Félix Houphouët-Boigny Abidjan-Cocody, Côte d'Ivoire. Revue Ivoirienne de Géographie des Savanes 2017;2:2521-2535.

3. Esdaile LJ, Chalker JM. "Mercury Problem in Artisanal and Small-scale Gold Mining". Chemistry European Journal. 2018;24(27):6905-6916. https://doi.org/10.1002/chem.201704840.

4. Zhang X, Siddiqi Z, Song X, Mandiwana K, Yousaf M, Lu J. "Atmospheric dry and wet deposition of mercury in Toronto". Atmospheric Environment 2012;50(1):60-65. https://doi.org/10.1016/j.atmosenv.2011.12.062.

5. Rogers JS, Huang PM, Liaw WK. "Chemical dynamics of mercury sorption and desorption of freshwater sediments". Chemical limnology 1981;21(1):174-180. https://doi.org/10.1080/03680770.1980.11896978.

6. Rust BR. "Sedimentation in fluvial and lacustrine environments". Hydrobiologia 1982;91:59-70. https://doi.org/10.1007/BF00940096.

7. Boucheseiche C, Cremille E, Pelte T, Pojer K. "Guide technique $\mathrm{n}^{\circ} 7$, pollution toxique et écotoxicologie : notion de base". Lyon, Agence de l'eau RhôneMéditerranée-Corse 2002. 83.

8. Koffi KM, Coulibaly S, Atsé BC, Kouamelan EP. "Survey of heavy metals concentrations in water and sediments of the estuary Bietri bay, Ebrie lagoon, Côte
d'Ivoire". Int. J. Res. Earth. Environ. Sci 2014;1(3):1-10.

9. Kouamé KDB, Yapo OB, Meite L. "Contamination Des Sédiments D'une Lagune Tropicale Urbaine Par Les Éléments Traces Métalliques (As, $\mathrm{Cd}, \mathrm{Cr}, \mathrm{Pb}, \mathrm{Zn}$ ) : Cas Des Baies Lagunaires De La Ville d'Abidjan (Côte D'ivoire)". Int. J. Pure App. Biosci 2016;4(6):204-217. https://doi.org/10.18782/2320-7051.2428.

10. Coulibaly S, Atse BC, Koffi KM. "Heavy metal contamination of matrices water-sediment and muscle of tilapia oreochromis niloticus of three fish farms in Ivory Coast". Agronomie africaine 2018;30(3):249-259.

11. Kinimo KC, Koffi MY, Marcotte S, N'Guessan LBK, Trokourey A. "Distribution trends and ecological risks of arsenic and trace metals in wetland sediments around gold mining activities in central-southern and south eastern Côte d'Ivoire". Journal of Geochemical Exploration. 2018;S0375-6742(17):30304-7, doi:10.1016/j.gexplo.03.013.

12. Mason RP, Zofia B, Gunnar H, Koffi MY, Mariame C, Safiatou C. "An assessment of the impact of artisanal and commercial gold mining on mercury and methylmercury levels in the environment and fish in Cote d'Ivoire". Science of Total Environment 2019;665:1158-1167. https://doi.org/10.1016/j.scitotenv.2019.01.393.

13. N'Da SA, Etilé RN, N'zi KG, Berté S, N'douba V. "Composition and Distribution of Zooplankton Relationship to Environmental Factor in a Tropical River: (Bagoe, Côte d'Ivoire)". International Research Journal of Biological Sciences 2015;4(11):1-11. ISSN 22783202.

14. Sanogo Y, Samake F, Kone A, Traoré D. "Diversité du peuplement ichtyologique de la rivière Bagoé (Bassin du Niger, Mali)". Agronomie Africaine 2015;27(1) :47-56.

15. Tanina DS, Bernard DK, Ernest AK, Gbombélé S, Amani MK, Konan EK et al. "Hydroclimatologie et dynamique de l'occupation du sol du bassin versant du Haut Bandama à Tortiya (Nord de la Côte d'Ivoire)", Revue électronique en sciences de l'environnement 2013;13(3). https://doi.org/10.4000/vertigo-14468.

16. Donkor AK, Adimado AA. "Influence of mining related activities on levels of mercury in water, sediment and fish from the Ankobra and Tano River basins in South Western Ghana". Environmental Systems Research. 2016;5:5-10 .https://doi.org/10.1186/s40068-016-0055-4.

17. CCME (Canadian Council of Environment Ministers). "Manuel des protocoles d'échantillonnage pour l'analyse de la qualité de l'eau au Canada". In CCME, Publications-Eau 2011, 219.

18. Ghestem JP, Crouzet C, Girardot N. "Estimation des fonds géochimiques en éléments traces des eaux de surface continentales et des eaux souterraines": Cahier des charges pour l'analyse et le prélèvement. Rapport final 2008, 47.

19. AFNOR. "Qualité de l'eau, recueil des normes françaises”. Éditions AFNOR, Paris 1997, 46.

20. CEAEQ (Quebec's Center of Expertise and Environmental Analysis). "Détermination de la conductivité : méthode électrométrique, MA. 115-Cond. 1.1, rév. 1, Ministère du Développement Durable, de l'Environnement et de la Lutte contre les changements climatiques". Québec 2015, 9.

21. AFNOR. "Qualité de l'eau- Dosage des matières en suspension- méthode par filtration sur filtre en fibres de verre". Edition AFNOR, Paris 2005, 10. 
22. Ibouily G. "Étude sédimentologique de la rade de Marseille Bouches-du-Rhone". Thèse de Doctorat 3è cycle, Université Aix-Marseille, France 1981, 130.

23. Müller. "Heavy metals in sediments from the Rheinchanges since 1971". Un-mschau in wissenschaft und technik 1979;79:778-783.

24. Bhuiyan MA, Parvez L, Islam M, Dampare SB, Suzuki S. "Heavy metal pollution of coal mine-affected agricultural soils in the northern part of Bangladesh". Journal of Hazardous Materials 2010;173(1-3):384-392. https://doi.org/10.1016/j.hazmat .2009.08.085.

25. Lecce SA, Pavlowsky RT. "Floodplain storage of sediment contaminated by mercury and copper from historic gold mining at Gold Hill, North Carolina, USA". Geomorphology 2014;206:122-132. https://doi.org/10.1016/j.geomorph.2013.10.004.

26. Wedepohl KH. "The composition of continental crust". Goechimica and Cocmochimica Acta. 1995;59(7):12171232.

27. Jayaprakash M, Urban B, Velmurugan PM, Srinivasalu S. "Accumulation of total trace metals due to rapid urbanization in microtidal zone of Pallikaranai marsh, South of Chennai, India”. Environmental Monitoring and Assessment. 2010;170:609-629. https://doi.org/10.1007/s10661-009-1261-6.

28. Zar JH. "Biostatistical analysis", $4^{\text {th }}$ Edition, Prentice Hall, Upper Saddle River 1999, 663.

29. Hakanson L. "An Ecological risk index for aquatic pollution control. A sedimentological approach". Water Research 1980;14(8):975 1001.https://doi.org/10.1016/0043.1354 (80)90143-8.

30. Thevenon F, Guédron S, Chiaradia M, Loizeau JL, Pote J. "(Pre-) historic changes in natural and anthropogenic heavy metals deposition inferred from two contrasting swiss alpines lakes". Aquat. Sci. Rev 2011;30:224-233. https://doi.org/10.1016/j.quascirev.2010.10.013.

31. Kwaansa-Ansah E, Agorku S, Nriagu J. "Levels of total mercury in different fish species and sediments from the Upper Volta Basin at Yeji in Ghana". Bulletin of Environmental Contamination and Toxicology 2011;86(4):406-409.

32. Bretzler A, Lalanne F, Nikiema J, Podgorski J, Pfenninger N, Berg M, Schirmer M. "Groundwater arsenic contamination in Burkina Faso, West Africa: predicting and verifying regions at risk". Sciences of Total Environment 2017;584:958-970. doi: 10.1016/j.scitotenv.2017.01.147.

33. Podgorski JE, Eqani SAMAS, Khanam T, Ullah R, Shen $\mathrm{H}$, Berg M. "Extensive arsenic contamination in high-pH unconfined aquifers in the Indus Valley". Science Advances 2017;3(8):e170093. https://doi.org/10.1126/sciadv.1700935.

34. Niane B, Moritz R, Guédron S, Ngom PM, Pfeifer HR, Mall I et al. "Effect of recent artisanal small-scale gold mining on the contamination of surface river sediment: Case of Gambia River, Kedougou", Journal Geochemical Exploration Part C 2014;144:517-527. https://doi.org/10.1016/i.gexplo.2014.03.028.

35. Kyereme YA, Donko AK, Golow AA, Yeboah PO, Pwamang J. "Mercury Concentrations in Water and Sediments in Rivers Impacted by Artisanal Gold Mining in the Asutifi District, Ghana". Research Journal of Chemical and Environmental Sciences 2015;3(1):40-48.

36. Gerardo M, Stephen AMC, Charles TD, Svetoslava T,
Steven W, Julio FA et al. "Mercury Contamination in Riverine Sediments and Fish Associated with Artisanal and Small-Scale Gold Mining in Madre de Dios, Peru”. Int. J. Environ. Res. and Public Health 2018;15(2):1584. https://doi.org/10.3390/ijerph15081584.

37. Lu XW, Zhang XL, Li LY, Chen H. "Assessment of metals pollution and health risk in dust from nursey schools in Xi'an". China Environment Research 2014;128:27-34.

https://doi.org/10.1016/j.envres.2013.11.007.

38. Donkor AK, Bonzongo JC, Nartey VK, Adotey DK. "Mercury in different environmental compartments of the Pra River Basin, Ghana". Science of the Total Environment. 2006;368(1):164-176. https://doi.org/10.1016/j.scitotenv.2005.09.046.

39. Gerson JR, Charles T, Driscoll TC, Heileen H-K, Emily SB. "Senegalese artisanal gold mining leads to elevated total mercury and methylmercury concentrations in soils, sediments, and rivers". Elementa Science of the Anthropocene. 2018;6:1-11. https://doi.org/10.1525/elementa.274.

40. Niane B, Guédron S, Feder F et al. "Impact of recent artisanal small-scale gold mining in Senegal: Mercury and methylmercury contamination of terrestrial and aquatic ecosystems". Science of the Total Environment. 2019;PIIS0048-9697(19)31090-3, 10.1016/j.scitotenv.03.108.

41. Lochu S, Duval M, Cassaï C, Talec P. "Guide méthodologique des diagnostics à mettre en œuvre au préalable des opérations de dragage de sédiments marins à l'île de la Réunion". 2017, 46.

42. Guedron S, Grangeon S, Lanson B, Grimaldi M. "Mercury speciation in a tropical soil association: consequence of gold mining on $\mathrm{Hg}$ distribution in French Guiana”. Geoderma. 2009;153:331-346. https://doi.org/10.1016/j.geoderma.2009.08.017

43. Thomassin JF, Touzé S, Baranger P. "Le mercure et ses composés : Comportement dans les sols, les eaux et les boues de sédiments". BRGM/RP-51890-FR 2003;119(20):4 Ann.

44. Guigues N, Corroller M. "Étude de l'influence des matières en suspension sur la concentration en phosphore, bore, cuivre, zinc et autres métaux lourds dans l'eau, en aval, d'une centrale nucléaire située dans la vallée de la Loire". BRGM/RP-52750-FR. 2004;75(60):ill., 2 Ann.

45. Abdoulaye DN, Ousmane T, Mohamed O, Khalid IN. "Turbidité et matières en suspension dans l'eau: application à l'évaluation des métaux contenus dans l'eau de la rive droite du fleuve Sénégal'. Larhyss Journal. 2013;14:93-105.

46. Jingying X, Dan B, Kleja HB, Anders L, Jurate K. "Influence of particle size distribution, organic carbon, $\mathrm{pH}$ and chlorides on washing of mercury contaminated soils". Chemosphere 2014;109:99-105. https://doi.org/10.1016/j.chemosphere.2014.02.058.

47. Ujevic I, Odzak N, Baric A. "Trace metal accumulation in different grain size fractions of the sediments from a semi-enclosed bay heavily contaminated by urban and industrial wastewaters". Water Research. 2000;34(11):3055-3061. https://doi.org/10.1016/S00431354 (99)00376-0.

48. Taylor KG, Boult S. "The role of grain dissolution and diagenetic mineral precipitation in the cycling of metals 
and phosphorus: A study of a contaminated urban freshwater sediment". Applied Geochemistry 2007; 22: 1344-1358.

https://doi.org/10.1016/j.apgeochem.2007.01.008.

49. Liu W, Moran CJ, Vink S. "Quantitative risk-based approach for improving water quality management in mining”. Environmental Sciences of Technology. 2011; 45 (17): 7459-7464. https://doi.org/10.1021/es201876c.

50. Wildi W, Dominik KJ, Loizeau J-L, Thomas RL, Favarger P-Y, Haller L et al. "River, reservoir and lake sediments contamination by heavy metals downstream from urban areas of Switzerland". Res. Manag. 2004;9(1):75-87. https://doi.org/10.1111/j.14401770.2004.00236.x.

51. Niamké KH, Kôkôh RE, Brou EN, Krazoua FG, Yei MSO. "Caractérisation des paramètres physiques et du taux de mercure des eaux dans un environnement d'orpaillage: cas de Kouaméfla dans le département d'Oumé (Centre de la Côte d'Ivoire)". Journal of Applied Geology and Geophysics 2020;8(1):48-56. https://doi.org/10.9790/0990-0801034856.

52. Konan KS, Yapi AHY, Akpetou KL, Gbamelé KS, Kouadio DL. "Assessment of the health risks associated with the ingestion of nitrates, arsenic, mercury contained in the groundwater in the gold mining environment". International Journal of Innovation and Applied Studies; Rabat. 2019;27(1):301-310.

53. Yapi YHA, Dongui BK, Trokourey A, Barima YSS, Essis Y, Etheb P. "Évaluation de la pollution métallique des eaux souterraines et de surface dans un environnement minier aurifère à Hiré (Côte d'Ivoire) ". International Journal of Biology and Chemical Sciences. 2014;8(3):1281-1289.

https://doi.org/10.4314/ijbcs.v8i3.41 